\begin{tabular}{|c|c|c|c|c|c|c|}
\hline \multirow{4}{*}{ Impact Factor: } & ISRA (India) & $=3.117$ & SIS (USA) & $=0.912$ & ICV (Poland) & $=6.630$ \\
\hline & ISI (Dubai, UAE & $=0.829$ & РИНЦ (Russia) & $=0.156$ & PIF (India) & $=1.940$ \\
\hline & GIF (Australia) & $=0.564$ & ESJI (KZ) & $=8.716$ & IBI (India) & $=4.260$ \\
\hline & JIF & $=1.500$ & SJIF (Morocco) & $=5.667$ & OAJI (USA) & $=0.350$ \\
\hline
\end{tabular}

\section{SOI: 1.1/TAS DOI: 10.15863/TAS International Scientific Journal Theoretical \& Applied Science}

p-ISSN: 2308-4944 (print) e-ISSN: 2409-0085 (online)

Year: 2019 Issue: $03 \quad$ Volume: 71

Published: 25.03.2019 http://T-Science.org
QR - Issue
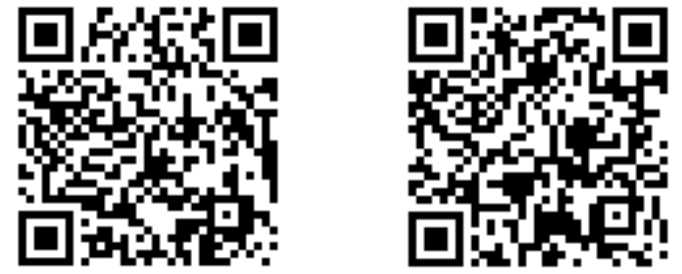

Shakhnoza Nurullaeva

Senior lecturer at the Department of Econometrics Tashkent State University of Economics

Tashkent, Uzbekistan

Nazira Ruzmetova

Senior lecturer at the Department of Econometrics

Tashkent State University of Economics

Tashkent, Uzbekistan

Maxbuba Muminova

Senior lecturer at the Department of Econometrics

Tashkent State University of Economics

Tashkent, Uzbekistan

Saodat Saidullaeva

Econometrics department teacher

Tashkent State University of Economics

Tashkent, Uzbekistan

\title{
CONSISTENCY OF ECONOMIC RELATIONS IN PROVIDING EMPLOYMENT IN THE REPUBLIC OF UZBEKISTAN
}

\begin{abstract}
In this article have been described economic relations in the Republic of Uzbekistan in the context of macroeconomic stabilization of the economy, improvement of the labor market, provision of real labor and employment in the workplace.

Key words: employment, labor, economic growth, labor market, unemployment, labor.

Language: English

Citation: Nurullaeva, S., Ruzmetova, N., Muminova, M., \& Saidullaeva, S. (2019). Consistency of economic relations in providing employment in the republic of Uzbekistan. ISJ Theoretical \& Applied Science, 03 (71), 14-18.

Soi: http://s-o-i.org/1.1/TAS-03-71-4 Doi: crossef https://dx.doi.org/10.15863/TAS.2019.03.71.4
\end{abstract}

\section{Introduction}

The Republic of Uzbekistan is stepping up in a new stage of development in social, economic and spiritual spheres. Transition of the republic to market relations has created a basis for radical renovation of the economy. These changes were initially reflected in labor relations and created the need for the formation and development of the labor market. The labor market plays an important role in the system of economic relations. The labor market, which is considered as an important component of the system of economic relations, is formed and operates on the basis of certain laws. The development of this marketplace plays an important role in addressing the employment problems of the population.

The President of the Republic of Uzbekistan Sh.M.Mirziyoev noted that "Employment service centers employed only 248 thousand people or $16.5 \%$ of the last year. The main reasons for this are the widespread forms and methods of business activities and the formalities in solving employment problems "[1]. The above-mentioned situation highlights the relevance of the chosen topic, focusing primarily on the issue of balancing the labor market balance and infrastructure, reducing the unemployment rate.

The Labor Code of the Republic of Uzbekistan and the Labor Code of the Republic of Uzbekistan [3] are important legal frameworks in the labor market development process in Uzbekistan. The legislation recognizes unemployment, the right to choose employment, guarantees of social protection against unemployment. These normative documents constitute an important basis for the employment of 


\begin{tabular}{|c|c|c|c|c|c|c|}
\hline \multirow{4}{*}{ Impact Factor: } & ISRA (India) & $=\mathbf{3 . 1 1 7}$ & SIS (USA) & $=0.912$ & ICV (Poland) & $=6.630$ \\
\hline & ISI (Dubai, UAE & $=0.829$ & РИНЦ (Russia & $=0.156$ & PIF (India) & $=1.940$ \\
\hline & GIF (Australia) & $=0.564$ & ESJI (KZ) & $=8.716$ & IBI (India) & $=4.260$ \\
\hline & JIF & $=1.500$ & SJIF (Morocco & $=5.667$ & OAJI (USA) & $=0.350$ \\
\hline
\end{tabular}

the population in improving the wellbeing of the population.

In the context of macroeconomic stabilization of the economy, improving the labor market within the framework of the market relations, ie realizing the actual demand and supply of labor force, forming new mechanisms for regulation of employment and effective labor force, creating conditions for free movement of labor as well as the mechanism of effective distribution of labor force in the labor market.

\section{Literature review}

In the context of this topic, many foreign and local experts are working on the formation and development of the labor market, its types, forms, performance mechanisms, labor market models, and unemployment reductions and employment regulation. It's about this

Anderson, B., M. Ruhs, B. Rogaly and S.Spencer [4] studied the role of contracts in terms of the labor force quintessential in terms of labor force demand, varied demand, and flexibility in business uncertainty. In this study, one-to-one attention is drawn to the forgetting of the other side of the proposal (that is, knowledge, skills and experience of labor force).

A study by S.Altorjai [5] on the impact of labor migration, the creation of favorable conditions for them (living and working rights) and short, medium and long term contracts, employment, and human resources turnover. The fact that local workers do not study the situation in the study limits the possibility of a complete conclusion on this issue.

Roger Lowenstein [6] studied how employment, competition, and wage in the countries with migrant workers and local labor force change employment compared to the employment rate. However, the demand and supply of labor in the country has not been studied, and the importance of these two factors in the labor market is not addressed.

The most important criterion for the qualitative characteristics of the labor market is the fact that it is the level of infrastructure development, the socioeconomic nature of the labor market infrastructure, its components, and some of its main functions and functions.
The scientific and theoretical analysis of the interdependence of the labor market infrastructure and its components, the method of complex assessment and prospecting of its development, as well as the main directions of the formation and development of state and non-state employment services, Sh. R. Holmuminov, N.U. It is reflected in the studies of Arabs [8].

Despite the fact that the above-mentioned research finds that there are some cases in the current modernization of the economy, achieving a high level of employment in the society is the most important macroeconomic objective; it requires research on a variety of theoretical and practical approaches to the analysis of the macroeconomic labor market mechanism.

\section{Research Methodology}

The labor market mechanism establishes the employment rate and wages of the population, ie the labor market is one of the main indicators that determine the welfare of the nation, the socioeconomic changes in society.

Therefore, in the deep study of the labor market is the selection of statistical data, economic analysis and issuance of conclusions based on econometric analysis.

\section{Analysis and results}

The labor market is based on demand and supply, as well as all markets. Demand for this is the need for a vacancy, and the offer - as an unwanted work force or a desire to change the place of work. Satisfaction of the demand and supply, on the one hand, is to occupy one or another position among the workers, and on the other. It is achieved through a competitive struggle between employers to attract the necessary number of skilled workforce. There are a number of conditions that need to be met to justify this fight. The most important of these conditions are the mobility of labor force and the proper location of production forces. Due to the resilience of the local population in line with our national capacities, attempts to develop regional labor markets in the country play a special role.

Table 1. Information on the age structure of the permanent population of the Republic of Uzbekistan.

\begin{tabular}{|c|c|c|c|c|}
\hline Indicators & 1991 & 2011. & 2017 & Change from 2017 to 1991 (\%) \\
\hline Total population & 20607,7 & 29123,4 & 32120,5 & 155,9 \\
\hline Younger than working age & 8883,7 & 9099,3 & 9665,7 & 108,8 \\
\hline Working-age adults & 10122,5 & 17804,7 & 19440,8 & 192,1 \\
\hline Older than working age & 1601,5 & 2219,4 & 3014 & 188,2 \\
\hline
\end{tabular}

Source: State Statistics Committee of Uzbekistan. 


\begin{tabular}{|c|c|c|c|c|c|c|}
\hline \multirow{4}{*}{ Impact Factor: } & ISRA (India) & $=\mathbf{3 . 1 1 7}$ & SIS (USA) & $=0.912$ & ICV (Poland) & $=6.630$ \\
\hline & ISI (Dubai, UAE & $=0.829$ & РИНЦ (Russia & $=0.156$ & PIF (India) & $=1.940$ \\
\hline & GIF (Australia) & $=0.564$ & ESJI (KZ) & $=8.716$ & IBI (India) & $=4.260$ \\
\hline & JIF & $=1.500$ & SJIF (Morocco & $=5.667$ & OAJI (USA) & $=0.350$ \\
\hline
\end{tabular}

If we look at the data from the table, it can be seen that in 2017 the population growth was 55.9 percent compared to 1991. This, of course, has led to a rise in working age in the Republic of Uzbekistan, leading to the problem of employment. This is because statistical data show that this indicator has grown by $92.1 \%$ in 2017 to 1991 and reached $19,440,800$ people.

This can have a negative impact on demand and supply. It is desirable to develop employment programs for the proper distribution of labor resources between the local and labor market in order to balance the difference between labor market and to ensure the social protection of working people in regions with sufficient labor resources. Of course, the number of enterprises in Uzbekistan is growing with the population growth. However, it is important to ensure the proportionality of the population in this area.

At present, it is desirable to take into account that there is a high number of unemployed (especially among women) between the graduates of secondary special and higher education institutions, especially among the working age population aged 40-50 years. It is a great achievement for the people of this age to have a certain experience in their specialties and to have the opportunity to teach their teenagers an opportunity to live up to their retirement age. The population of working age between the ages of 40 to 50 years, compared to 1991 , increased by 3 to 3693,800 in 2017 and amounted to $1,868,000$ (Table 2).

Table 2. Composition of permanent population of the Republic of Uzbekistan aged 15-50 (thousand people)

\begin{tabular}{|c|c|c|c|c|c|c|}
\hline \multirow{2}{*}{ Age } & \multicolumn{2}{|c|}{1991} & \multicolumn{2}{c|}{2017} & \multicolumn{2}{c|}{ Change from 2017 to 1991} \\
\cline { 2 - 6 } & men & women & men & women & men & women \\
\hline $40-49$ & 614,4 & 614,3 & 1825,8 & 1868 & 3,0 & 3,0 \\
\hline $15-24$ & 1970,1 & 1964,7 & 2981,8 & 2852,6 & 1,5 & 1,5 \\
\hline
\end{tabular}

Source: State Statistics Committee of Uzbekistan

According to the data of the table, in 2017 the number of able-bodied people under the age of 40-49 increased by 1.5 times compared to 1991 and 1.5 times in the age group of 15-24, which, in 1991, amounted to 23.3 years of age by 2017 , this figure is 28.5 years, which means that the average age of the population of the republic is 5.2 years old. In this regard, it is necessary to focus on the creation of new enterprises and job creation.

This situation can lead to the problem of continuity of activity, with further increase in the number of enterprises, which, in turn, requires paying attention to the current situation when the number of enterprises is relatively higher than the population size. This, in turn, should be based on the need to create small businesses, crafts and home-based businesses, and to rebuild them in the future, depending on the needs of the population.
It should also be noted that public finance, credit, investment and tax policies, incentives for small businesses, the application of changing labor procedures, and other measures to promote and maintain jobs. This requires a profound study of labor markets, research and analysis of factors affecting it. External and internal factors affecting the labor market should be emphasized separately.

External factors - economic crisis, structural changes in the economy, development of property relations, monetary and financial policy of the state.

Internal factors include the demographic situation in the country, training and retraining of personnel, migration, changes in the composition of the population with gender and age groups. Studying these factors will help to identify the following trends and trends in the labor market in modern conditions (Figure 3). 


\begin{tabular}{|c|c|c|c|c|c|c|}
\hline \multirow{4}{*}{ Impact Factor: } & ISRA (India) & $=\mathbf{3 . 1 1 7}$ & SIS (USA) & $=0.912$ & ICV (Poland) & $=6.630$ \\
\hline & ISI (Dubai, UAE & $=0.829$ & РИНЦ (Russia & $=0.156$ & PIF (India) & $=1.940$ \\
\hline & GIF (Australia) & $=0.564$ & ESJI (KZ) & $=8.716$ & IBI (India) & $=4.260$ \\
\hline & JIF & $=1.500$ & SJIF (Morocce & $=5.667$ & OAJI (USA) & $=0.350$ \\
\hline
\end{tabular}

Internal and external factors are basically defined in the labor market trends and traditions

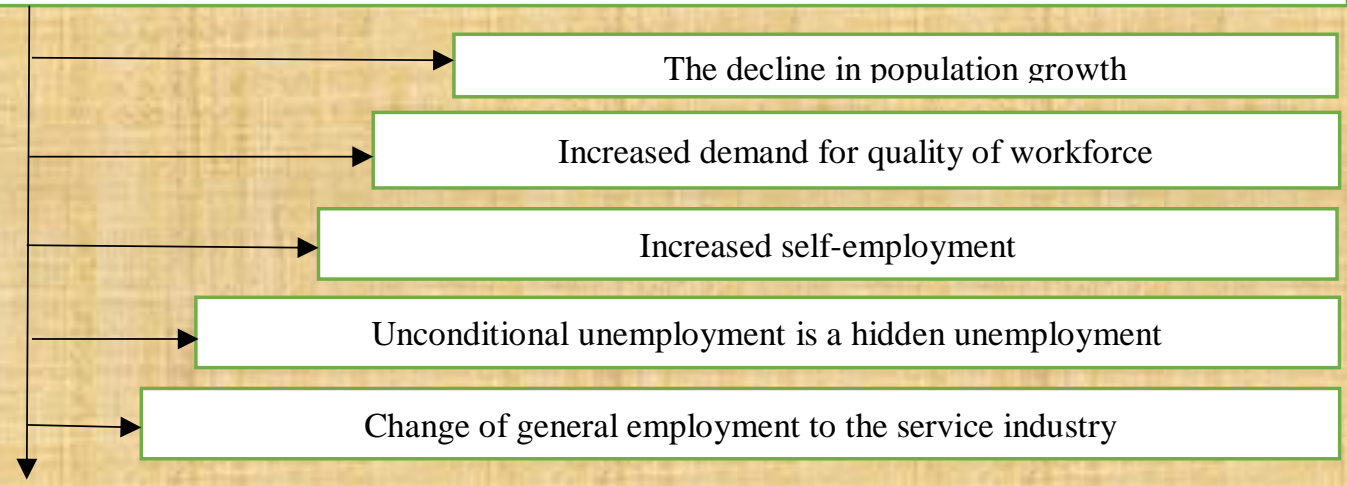

The share of the most active young men in the structure of labor has diminished, and that the demographic situation is changing over the past few years

Picture 3. Internal and external factors are basically defined in the labor market trends and traditions.

- Transformation of market principles and sociolabor relations into the creation of new mechanisms for the regulation of employment and the effective distribution of labor force has created new trends in the labor market. Here are a few things to do:

- $\quad$ - To determine the essence of the labor market as an economic category;

- $\quad$ - Explaining the nature of the labor market by studying the theoretical foundations;

- $\quad$ - identifying the factors influencing the demand and supply of labor in the labor market and evaluating their place of business;

- - Development of the econometric model of the mechanism of the state of the Republic of Uzbekistan to analyze the state of the population employment and achieve effective distribution of labor force;
- $\quad$ - In Uzbekistan, young people are required to develop and implement practical recommendations aimed at studying and raising the effectiveness of the labor market.

\section{Conclusion/Recommendations}

In summary, a decline in the number of employed people, a significant change in the structure of employment in the economic sectors, and the expansion of informal employment volumes. It is crucial to define the socioeconomic development trends, to improve the mechanism of efficient distribution of labor power through the system of econometric models, and to develop a program of structural transformation of the population employment. Implementation of these tasks, in turn, plays an important role in the employment of the population of the country.

\section{References:}

1. (2017). Report of the President of the Republic of Uzbekistan Shavkat Mirziyoev at the enlarged meeting of the Cabinet of Ministers dedicated to the main results of socio-economic development of the country in 2016 and the most important priorities of the economic program for 2017. The newspaper "Khalq szhi", January 16, 2017, №11 (6705).

2. (1998). The Law of the Republic of Uzbekistan "On employment of the population law" (new edition). Tashkent: Sharq.
3. (1996). Labor Code of the Republic of Uzbekistan. (p.256). Tashkent: Justice.

4. Anderson, B., Ruhs, M., Rogaly, B., \& Spencer, S. (2006). "Fair enough? Central and Eastern European migrants in low-wage employment in the UK", COMPAS. http://www.irr.org.uk/pdf/Fair_Enough.pdf

5. Altorjai, S. (2013). "Over-qualification of immigrants in the UK", Institute for Social and Economic Research. University of Essex. https://www.iser.essex.ac.uk/research/publicatio ns/workingpapers/iser/2013-11.pdf 


\begin{tabular}{|c|c|c|c|c|c|c|}
\hline \multirow{4}{*}{ Impact Factor: } & ISRA (India) & $=\mathbf{3 . 1 1 7}$ & SIS (USA) & $=0.912$ & ICV (Poland) & $=6.630$ \\
\hline & ISI (Dubai, UAE & $=0.829$ & РИНЦ (Russia & $=0.156$ & PIF (India) & $=1.940$ \\
\hline & GIF (Australia) & $=0.564$ & ESJI (KZ) & $=8.716$ & IBI (India) & $=4.260$ \\
\hline & JIF & $=1.500$ & SJIF (Morocco & $=5.667$ & OAJI (USA) & $=0.350$ \\
\hline
\end{tabular}

6. (2006). Roger Lowenstein. An excellent description of the academic debate over how to measure the labor market impact of immigration and how this discussion has influenced the U.S. policy debate. "The Immigration Equation," New York Times Magazine, July 9, 2006.
7. Abdurakhmanov, Q. X. (2009). Labor economics (textbook). (p.512). Tashkent: Mehnat.

8. Holmuminov, S. R., \& Arabov, N. U. (2016). Labor Market Infrastructure. Educational manual. (pp.150-155). Tashkent: Science and Technology. 